\title{
ГРАММАТИЧЕСКАЯ СУБСТАНТИВНАЯ ОМОГРАФИЯ В РУССКОМ ЯЗЫКЕ
}

\section{GRAMMATICAL SUBSTANTIVAL HOMOGRAPHY IN RUSSIAN}

\author{
ЕЖИ КАЛИШАН
}

\begin{abstract}
This article is devoted to characterizing one of the main areas of contemporary Russian stress homography (i.e. the relationship between words that are spelled in the same way but pronounced differently as a result of different word stress). The author's aim is to attempt to describe all kinds of grammatical (paradigmatical) substantival homography that manifests itself in correlations between inflectional forms of the same lexeme such as учителя - учителя, письма - письма, (по) снегу - (на) снегу, еtс.
\end{abstract}

Jerzy Kaliszan, Uniwersytet im. Adama Mickiewicza w Poznaniu, Poznań - Polska.

Применительно к русскому языку под омографией вообще, называемой также графической омонимией, обычно понимается соотношение слов, пишущихся одинаково, но произносящихся по-разному за счет разницы в ударении, напр.: мука 'страдание' - мука 'продукт питания', мукой - мукой, угольная - угольная, угольными - угольными, трусить - трусить, трусил - трусил, верхом (нареч.) 'по верху' - верхом (нареч.) 'сидя на лошади', сволочь (сущ.) - сволочь (глаг.), знаком (сущ.) - знаком (прил.), белка 'животное' - белка (к белок), ношу (сущ.) - ношу (глаг.), мою (глаг.) - мою (местоим.), ноги - ноги, (к) лугу - (на) лугу, белите - белите.

Приведенные примеры показывают, что русские омографы можно разделить по крайней мере на три типа, принимая во внимание различия в лексических и/или грамматических значениях компонентов омографической корреляции. Так, в случае мука - мука, мукой-мукой, угольная - угольная, угольными - угольными, трусить - трусить, трусил - трусил, верхом - верхом компоненты пар обладают разным лексическим значением при одинаковом грамматическом значении; в парах типа сволочь - сволочь, знаком - знаком, белка - белка, ночу - ношу, мою - мою отдельные их компоненты имеют разное лексическое значение и разное грамматическое значение; в случае ноги - ноги, лугу - (на) лугу, белите - белите имеем дело с омографами, обладающими одинаковым 
лексическим значением при различном грамматическом значении. Омографы первого типа принято называть лексическими, второго типа - лексико-грамматическими, третьего типа - грамматическими или парадигматическими ${ }^{1}$.

Среди указанных трех типов русской омографии особого внимания, на наш взгляд, заслуживает грамматическая омография, так как в отличие от лексической и, тем более, лексико-грамматической омографии ей присуща определенная упорядоченность, известная стандартность, можно даже сказать - системность. При этом наиболее ярким признаком системности обладает субстантивная грамматическая омография. Именно она и является объектом предлагаемого здесь анализа. Анализ осуществляется на материале различного рода словарей современного русского языка - омографических, грамматических, орфографических, орфоэпических и др. ${ }^{2}$

Грамматическая (парадигматическая) субстантивная омография, т.е. соотношение одинаковых по написанию разноударных словоформ одной субстантивной лексемы, напрямую обусловлена подвижностью русского словесного ударения. Она представлена шестью типами корреляций:

(1) корреляцией форм родительного и винительного падежей ед. числа с формой именительного падежа мн. числа у одушевленных существительных м. рода типа доктор, тетерев;

(2) корреляцией формы родительного падежа ед. числа с формой именительного падежа мн. числа у одушевленных существительных ж. или общ. рода типа вдова, коза, сирота;

(3) корреляцией формы родительного падежа ед. числа с формами именительного и винительного падежей мн. числа у неодушевленных существительных м., ж. или ср. рода типа дом, рука, место, вино;

1 Ср.: А.И. М е л ь н и к о в а, К вопросу о русских омографах, „Русский язык в школе" 1974, № 4; ее же, Пути возникновения и развития омографии в русском языке. „Русский язык в школе” 1988, № 4; Н.П. К о л е с н и к о в, Система словесных омонимов в русском языке, [в:] ХІІ научная сессия филологического факультета. План работы и тезисы докладов, Тбилиси 1968; М.Г. П е т р е н к о, ЯВление омографии в современном русском языке. Автореф. дисс. ...канд. филол. наук, Одесса 1987.

2 В частности мы опирались на материал следующих словарей: А.А. 3 а л и 3 н я к, Грамматический словарь русского языка, Москва 2008; Русский орфографический словарь под ред. В.В. Лопатина, Москва 2007; М.В. 3 а р в а, Русское словесное ударение, Москва 2001; И.Л. Р е $з$ н и ч е н к о, Словарь ударений русского языка, Москва 2010; А.В. В е н ц о в, Е.В. Г р у д е в а и др., Словарь омографов русского языка, Санкт-Петербург 2004; Ю.Н. Г р е б е н е в а, Словарь омографов русского языка, Ливны 2009; Л.К. Г р а у д и н а, В.А. И ц к о в и ч, Л.П. К а т л и н с к а я, Грамматическая правильность русской речи. Стилистический словарь вариантов, Москва 2004. 
(4) корреляцией форм дательного и второго предложного (местного) падежей ед. числа у неодушевленных существительных типа лес, берег;

(5) корреляцией форм родительного, дательного и предложного изъяснительного падежей ед. числа (а при наличии полной числовой парадигмы - также и форм именительного и винительного падежей мн. числа) с формой второго предложного (местного) падежа ед. числа у существительных ж. рода типа тень, пыль;

(6) корреляцией форм второго родительного и второго предложного (местного) падежей у существительных типа снег, бок.

Корреляции (1) типа образуются формами около 70 лексем. Кроме указанных существительных доктор, тетерев, к ним относятся кучер, мастер, повар, профессор, учитель, овод, перепел и др. Каждая из этих лексем способна создавать по две пары омографов: доктора (род. ед.) - доктора (им. мн.), доктора (вин. ед.) - доктора (им. мн.); тетерева (род. ед.) - тетерева (им. мн.), тетерева (вин. ед.) - тетерева (им. мн.). В сумме, таким образом, потенциальное число грамматических омографов данного типа достигает около 140 корреляций. Они составляют принадлежность флективной парадигмы как существительных, имеющих стандартные -á-формы им. пад. мн. числа (доктор, егерь, мастер, юнкер 'воспитанник училища', овод, перепел, тетерев и под.), так и существительных, у которых -á-форма им. мн. употребляется альтернативно с формой на -ы (инспектор, слесарь, шкипер, шулер, пудель, ястреб и т.п.).

Корреляции (2) типа, по данным Грамматического словаря русского языка А.А. Зализняка, свойственны 20 именам существительным, к которым наряду с указанными bдова, коза, сирота относятся голова 'должностное лицо', сорвиголова, сноха, старшина, слуга, блоха, дрофа, змея, овияа, оса, свинья и др. Каждое из этих имен образует по одной паре омографов: вдовы (род. ед.) - вдовы (им. мн.), козы (род. ед.) - козы (им. мн.), сироты (род. ед.) - сироты (им. мн.). Следовательно, число возможных грамматических омографов в данном случае соответствует числу самих лексем, образующих эти омографы.

Корреляции (3) типа - это такие пары омографов, как дома (род. ед.) - дома (им. мн.), дома (род. ед.) - дома (вин. мн.), руки (род. ед.) - руки (им. мн.), руки (род. ед.) - руки (вин. мн.), места (род. ед.) - места (им. мн.), места (род. ед.) - места (вин. мн.), вина (род. ед.) - вина (им. мн.), вина (род. ед.) - вина (вин. мн.). Эти корреляции представляют собой наиболее многочисленный пласт субстантивной грамматической омографии. Их потенциальное число составляет свыше 900 омографических рядов. По данным Грамматического словаря русского языка А.А. Зализняка, они обеспечиваются взаимоотношением соответствующих словоформ 240 имен подтипа дом (вечер, город, колокол, кузов, лес, образ 
'икона', парус, поезд, сорт, холод и др.), в том числе и имен с колеблющимся окончанием (-á или -ы) им./вин. падежей мн. числа (bымnел, грейдер, джемпер, крейсер, рупор, трактор и др.); 158 имен подтипа рука (борозда, вина, губа, доха, изба, нужда, полоса, семья, сосна, страна и т.п.); 19 имен подтипа место (дело, войско, зеркало, облако, стадо, тело, море, поле, сердие и т.п.); 38 имен подтипа вино (волокно, долото, кольио, кайло, окно, письмо, число, ядро, яйцо и под.).

Корреляции (4) типа обнаруживаются в парадигме склонения около 100 имен существительных (по подсчетам Л.К. Граудиной). Кроме уже указанных лес, берег, к таким существительным относятся снег, долг, воз, край, клей, бой 'битва', бок, пол 'настил', сад, дом, нос, спирт и пр. Каждое из них обладает одной парой омографических словоформ: лесу (дат.) - (в) лесу (местн.), берегу (дат.) - (на) берегу (местн.). Таким образом, число данного рода пар омографов в русском языке адекватно числу образующих эти пары субстантивных лексем.

Корреляции (5) типа наблюдаются в деклинационных парадигмах около 35 существительных, к которым наряду с уже указанными тенъ, пыль принадлежат бровь, глубь, грязь, даль, ось, рысь 'быстрый аллюр', ночь, степь, щель и др. Большинство таких существительных (свыше $80 \%$ ) имеют полную числовую парадигму и обладают пятью рядами омографических форм, образуемыми соотношением формы местного падежа (локатива) с каждой из омоформ род., дат., предл. (изъяснительного) падежей ед. числа и им. и вин. падежей мн. числа, напр.: (в) тени - (от) тени, (в) тени - (к) тени, (в) тени - (о) тени, (в) тени - тени (им. мн.), (в) тени - тени (вин. мн.). Остальные же существительные, ввиду отсутствия у них множественной парадигмы, образуют по три пары омографов внутри парадигмы ед. числа, напр.: (в) пыли - (от) пыли, (в) пыли - (к) пыли, (в) пыли - (о) пыли. В сумме в сфере существительных ж. рода на согласный, имеющих особую форму локатива, можно обнаружить около 160 пар грамматических омографов.

Корреляции (6) типа - это акцентные оппозиции вторых родительного и предложного падежей существительных м. рода на согласный. На основе словарей современного русского языка можно выявить около 40 таких оппозиций. Приведем некоторые из них: (много) снегу - (в, на) снегу, (стакан) спирту - (в, на) спирту, (около) часу - (в первом) часу, (с) краю - (на) краю, (с правого) боку - (в, на) боку, (слезть с) возу - (на) bозу. Стоит подчеркнуть, что за вычетом форм родительного партитивного (снегу, спирту, клею, пуху, чаду, чаю), которые, кстати, явно идут на убыль, большинство форм второго родительного, вступающих в омографические отношения с формами второго предложного, а иногда даже и сами формы второго предложного, актуально функцио- 
нируют лишь в составе фрезеологизмов или лексикализованных (большей частью - адвербиализованных) предложных сочетаний, напр.: с году на год, без роду, без племени, ни шагу, на каждом шагу, с глазу на глаз, до сbетy, на сbетy, с ходу, на ходу, с виду, на виду, ни слуху ни дуxy, как на дуxy 'откровенно, ничего не утаивая'.

Итак, грамматическая омография в сфере имен существительных представляет собой явление, весьма интересное как в качественном, так и количественном аспекте: специфически проявляясь в отдельных группах различных по морфологическим и акцентным характеристикам субстантивных лексем, она находит выражение в 1300-1400 бинарных корреляциях парадигматически связанных словоформ. Указанными и проиллюстрированными выше типами корреляций практически исчерпываются возможности субстантивной грамматической омографии. Вне этих корреляций можно отметить всего лишь несколько маргинальных, крайне изолированных случаев омографического соотношения грамматических форм в пределах одной субстантивной лексемы. К ним относятся такие пары словоформ, как волос (им. ед.) - волос (род. мн.), волос (вин. ед.) - волос (род. мн.), груди (род. ед.) - груди (им. мн.), груди (род. ед.) - груди (вин. мн.), груди (дат. ед.) - груди (им. мн.), груди (дат. ед.) - груди (вин. мн.), (о, в, на) груди (предл. ед.) - груди (им. мн.), (о, в, на) груди - груди (вин. мн.) и, возможно, некоторые другие. 
